\title{
PSYCHE.
}

\section{THE AMERICAN SPECIES OF THE THYSANOURAN GENUS SEIRA.}

\author{
BY F. L. HARVEY, ORONO, ME.
}

The only species of the genus Seira that have been reported from North America are Seira buskii Lubbock and Seira purpurea Schött, the former from New York and the latter from California. Below is given a description of a new species from Maine belonging to this genus and notes upon $S$. buskii Lubbock from specimens taken in Maine. There is another apparently undescribed species in this region which is related to $S$. pruni Nicolet, in having the head and first thoracic segment yellowish and the body purple. We withhold a description of it at present prefering to study it farther. The detailed notes on $S$. buskii Lubbock may aid in further defining this species, and the description of $S$. purpurea Schött may prove interesting to entomologists who have not access to Schött's paper.

Seira mimica, n. sp. Body fusiform, slightly broadest at the fourth segment. General color pale dirty yellow or grayish with silver reflections. A deep purple interrupted band extending along the sides of the body. Body armed with numerous long dark colored plumose bowed hairs, which are very conspicuous on the head and anterior part of the mesonotum giving a shaggy appearance to the insect. These bowed hairs are arranged in transverse rows upon the middle of the dorsum of the mesonotum, metanotum, and on the first three body segments, the long fourth segment bearing about three or four rows.

Head broadly oblong, one-fifth longer than wide. A purple band along the anterior border, connecting the antennae, including the darker eye patches, and extending to the cheeks when it broadens and covers most of the anterior side of the head.

Antennae nearly two-thirds the length of the head and body; ratio $8: 13$ nearly, rather stout, purple, plumose hairy; basal joint and base of second joint pale, distal ends darker, third and fourth joints full purple; basal joint short about one-half second, second and third nearly equal, fourth slightly longer. Mesonotum bordered anteriorly and at the sides with purple which does not show plainly in the dorsal view as the dense fringe of hairs conceals the color which shows well in rubbed or balsam specimens.

Metanotum and the first and second body segments unmarked on the dorsum, but purple spotted on the sides. Posterior border of the third, fourth and fifth body segments and the whole of the sixth purple. The fourth segment, which is as long as the five preceding together, bears a purple spot upon each side near the middle and outer edge of the dorsal view.

Elater long, slender, pale yellow, hairy. Dentes annulated, the ventral edges tubercled with about two tubercles to each ring, 
ventral surface marked by fine transverse anastomosing reticulations. Mucrones ending in a curved claw which is armed with a prominent tooth near the end.

Legs rather long, purple, plumose hairy. Claws stout longitudinally, finely striate, and bearing three small teeth on the inner edge, and one on the outer edge. A single tenent hair clubbed at the end and extending nearly the length of the claw. Shorter claw plain.

Common about the windows of the college buildings where it has climbed to the fourth story in Coburn Hall

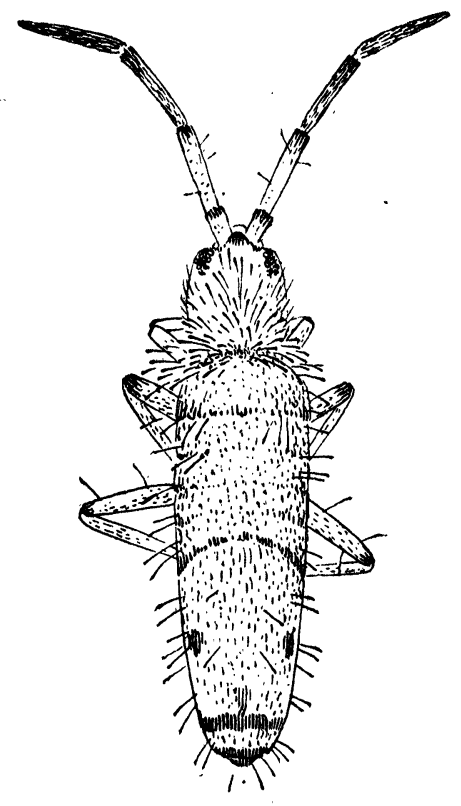

Seira mimica, $\mathrm{x} 3$.

which was built only four years ago. Found also about paper waste in the cellar and among books on library shelves. It loves warm, dry situations. Several spent the winter in the cracks about a window, within a foot of a large steam coil and appeared to enjoy it. Very active, running by starts. Very restless in captivity. A good jumper. A large number observed and examined during 1890-94, Orono, Me., F. L. Harvey.

This insect is more like Seira nigromaculata Lubbock than any described species, agreeing in size, habit and numerous clubbed hairs, but differing in the color and arrangement of the color patches.

It may be known by its dirty yellow ground color and markings of dark purple, like that of a dark grape or
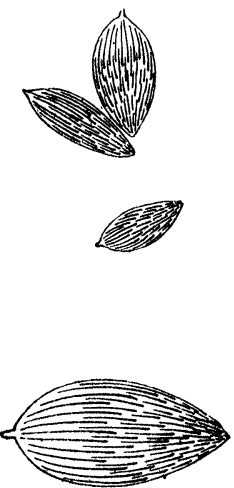

Seira mimica; scales, $\mathrm{x} \times 50$ and 250.

plum, and by its long antennae, long fourth abdominal segment, and shaggy appearance. It is named Seira mim$i c a$, because the form of the four posterior segments of the body, the color markings and the bowed hairs combined suggest the head of a rat or squirrel.

The drawings of the insect $(\times 30)$ were made by $\mathrm{Mr}$. J. H. Emerton from 
live specimens ; those of the scales, from slides prepared by the writer, $\times$ I 50 and 250. The head of the insect is more nearly round and more narrowed behind than shown in the drawing, and the body is too wide at the mesonotum, the body being widest at the beginning of the long fourth body segment and sloping gradually to the head.

Seira buskii Lubbock, Monograph Collem. p. 145; Fig. Pl. 22. Dark violet when mature. Younger specimens paler but the color disposed as in the adults. Dorsum of body and antennae violet. Head, proximal segments of antennae, upper part of femora, under surface of body and elater yellowish. Legs shaded with purple. Eyes eight on conspicuous dark patches which extend backward a little on the cheeks and are joined in front by a wide band.

Head conspicuous by its yellow color contrasting with the dark violet of the mesonotum. Nearly round or broadly oval slightly longer than broad.

Antennae purple or pale violet excepting the basal joint and base of the second joint which are yellowish brown. Second joint equal or shorter than the third. Fourth joint somewhat longer than the third. Basal joint short.

Body fusiform, broadest at the fifth segment. Sixth body segment longer than the three preceding. Thoracic bowed hairs conspicuous. Body clothed with scattered bowed hairs which are near the posterior part of the body and often $133 \mu$ long.

Elater long, hairy. Dentes annulated with numerous narrow rings. Hind legs longest. Feet all alike. Small claw plain. Large claw armed with three small teeth in the inner face and one on the outer margin. A single tenent hair from 30 to $40 \mu$ long and extending nearly to the end of the claw, curved, swollen and beaked at the end on the side toward the claw.

Scales about $3.5 \mu$ long, variable in width, sometimes only half as broad as long, oblong, lanceolate to ovate, the widest part near the base. Pedicil rather short and stout, markings as shown in Lubbock's Monograph, Pl. 7I for Seira buskii Lubbock.

We give detailed measurements of two specimens which will show the variation.

No. I. - Total length, exclusive of elater, I. $3 \mathrm{~mm}$.; head, .29 mm. long, .23 mm. broad; antennae, $.532 \mathrm{~mm}$.; joints, .053, .133, .146, $.2 \mathrm{~mm}$. Body r.or $\mathrm{mm}$. long, .27 mm. broad at the fifth segment; sixth segment, .319 $\mathrm{mm}$. as long as three preceding; spring, $.605 \mathrm{~mm}$. long; manubrium, .339; dentes and mucrones together, . $266 \mathrm{~mm}$.

No. 2. - Total length, I.72 mm.; head .319 x .319 mm.; antennae, . $77 \mathrm{~mm}$.; segment $.05, .239, .239$ and $.25 \mathrm{~mm}$. Body I.4 mm.; sixth segment, .372 as long as the two preceding; spring, .64 mm.; manubrium,.239 $\mathrm{mm}$.; dentes and mucrones, $.399 \mathrm{~mm}$.

If Lubbock's measurements of $S$. buskii ( $1-15$ in.) express an average, then our specimens are smaller, but if the extreme size, then the size is about the same, as some specimens measured were $1.75 \mathrm{~mm}$.

Habitat. Lubbock says his specimens were only found in greenhouses and hot-houses and he doubts whether the species is indigenous to Great Britain. Our specimens were found in the cellar of Coburn Hall at the Maine State College where boxes from foreign localities have been unpacked. The specimens are abundant under rubbish, among old papers and under boards on the floor and about the window sills. We have never taken it in the upper floors of the building where S. mimica n. sp. is common, though both species 
occur in the cellar. We took one specimen of what appeared to be this species from under the bark of a dead maple tree which would indicate that it is possibly indigenous. It is reported from New York by Mr. Macgillivray (Canad. Ent. Dec. r89i, p. 272) but under what conditions is not mentioned.

Remarks. The meagre description given by Lubbock in his monograph permits us to make but few comparisons of the characters of our specimens with $S$. buskii, yet though our specimens differ in the shorter, basal, antennal joint and broader band between the eyes, we see no reason for separating our specimens, for they agree exactly in form and other color markings.

Seira purpurea Schött, Beitrage zur Kenntniss Kalifornischen Collembola, Bihang Kongl. Svensk. vet. akad. handl. bd. 17 afd. iv, no. 8, p. I7, Pl. IV. (fig. I). Flava, signaturis purpureis quae in segmento thoracico tertio et in segmento abdominis primo secundoque fascias, totam aream segmenti non occupantes, formant. Segmenta abdominalia cetera purpurea. Long. 2-I, $5 \mathrm{~mm}$.

Da die Gattungen Entomobrya Rondani und Sira Lubbock sich nur durch das Vorhandensein oder Nichtvorhandensein von Schuppen unterscheiden, so ist es natürlich unmöglich die Gattung der hierhergehörenden Formen zu bestimmen, da nur in Weingeist conserviertes Material vorliegt. Wenn ich aber nun obige Form zur ersten
Gattung führe, so geschieht dies nur wegen der Zeichnung derselben. Diese erinnert insofern an diejenige bei unseren Sira-arten, dass keine Fascien mit scharf markierten Konturem wie bei allen bisher bekannten zweifarbigen Entomobyra-formen vorhanden sind, sondern nur langgestreckte Flecke, die one scharfe Begrenzung in die Grundfarbe übergehen.

Die Form ist ausnehmend schön und von den schwedischen Arten der Gattung Sira Lubbock wohl unterschieden. Das erste Thoracalsegment ist rotviolett, das zweite oben ganz hell, hat aber an der Kante einen dunklen Rand, welcher von dem ganz. dunkel gefärbten Basalglied des zweiten Extremitätenpaares, das wie die übrigen dunkle Cozalglieder hat, nach der entgegengesetzten Seite verläuft. Das dritte Thoracalsegment und die beiden ersten $A b d o m i-$ nalsegmente sind ungefähr gleich und mit violetten Querbändern versehen, die sich nur über die Dorsalfläche der Segmente erstrecken, wohingegen die Seiten gelbweiss sind. Das dritte und vierte Abdominalsegment sind völlig violett, das fünfte und sechste von gemischtem Colorit. Das Manubrium der Gabel und ein kleinerer teil der Dentes sind schwach violett, der übrige Teil und die Endsegmente ungefärbt. Der Kopf ist hell, die Augen stehen auf schwarzen Elecken mit einer dunklen Verbindungslinie zwischen sich. Die Antennenglieder sind schwach violett, heller nach den Spitzen hin. Die Abdominalsegmente, besonders die hintern, sind mit dichten Haaren versehen, die noch dichter auf den beiden Seiten sind und sich nach den Dentes furculae fortsetzen, auch in der Nackenregion befinden sich solche Haare.

\section{A NEW FAMILY OF FOSSIL BEETLES.}

In a recent paper on the fossil insects of Rott on the Rhine (Abh. naturf. ges. Halle, $\mathrm{xx}$ ) Schlechtendahl establishes a new family
Palaeogyrinidae on a beetle showing a combination of the characters of Gyrinidae and Dytiscidae. Extinct types of insects of as high a grade as families are extremely rare in the tertiaries. 

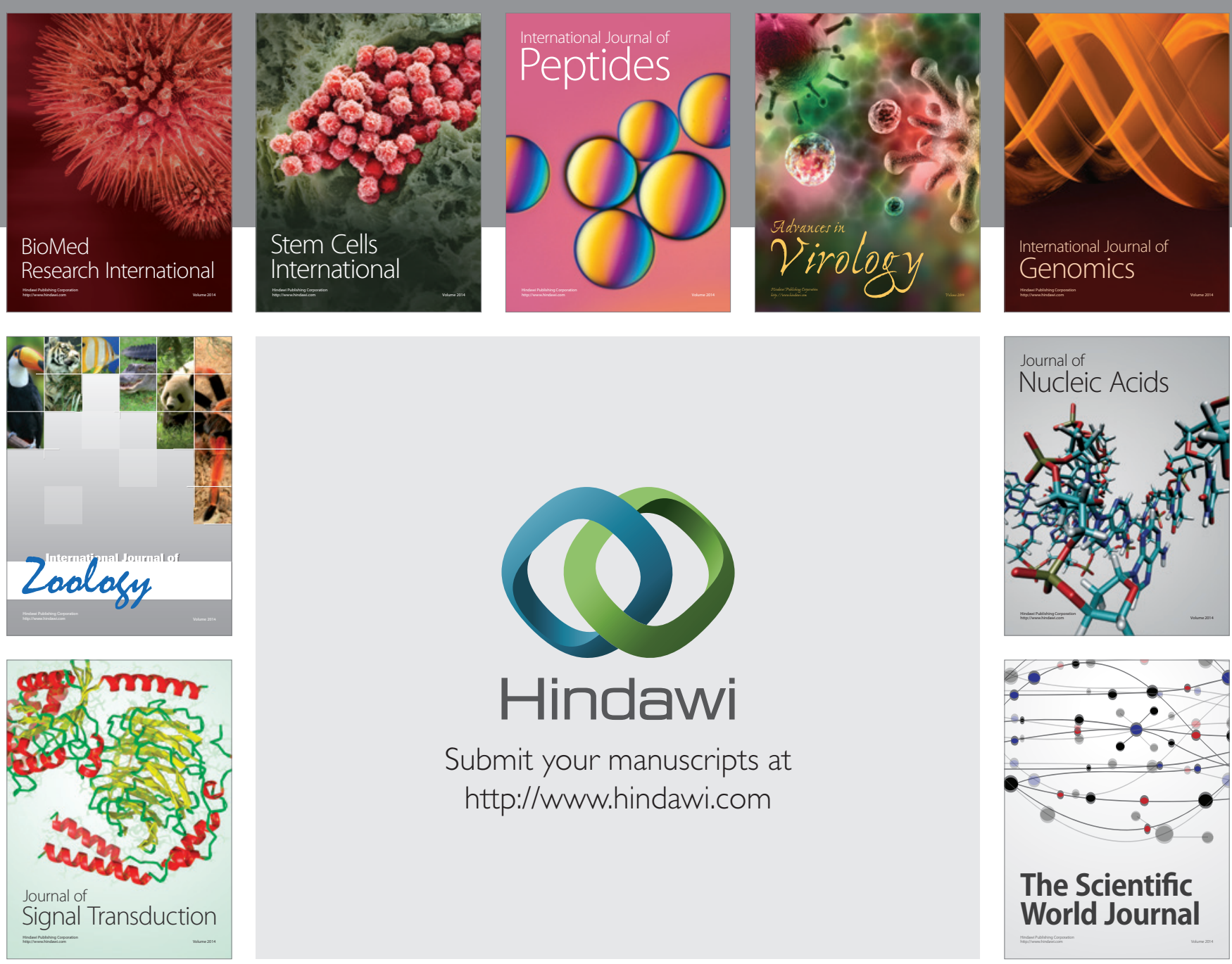

Submit your manuscripts at

http://www.hindawi.com
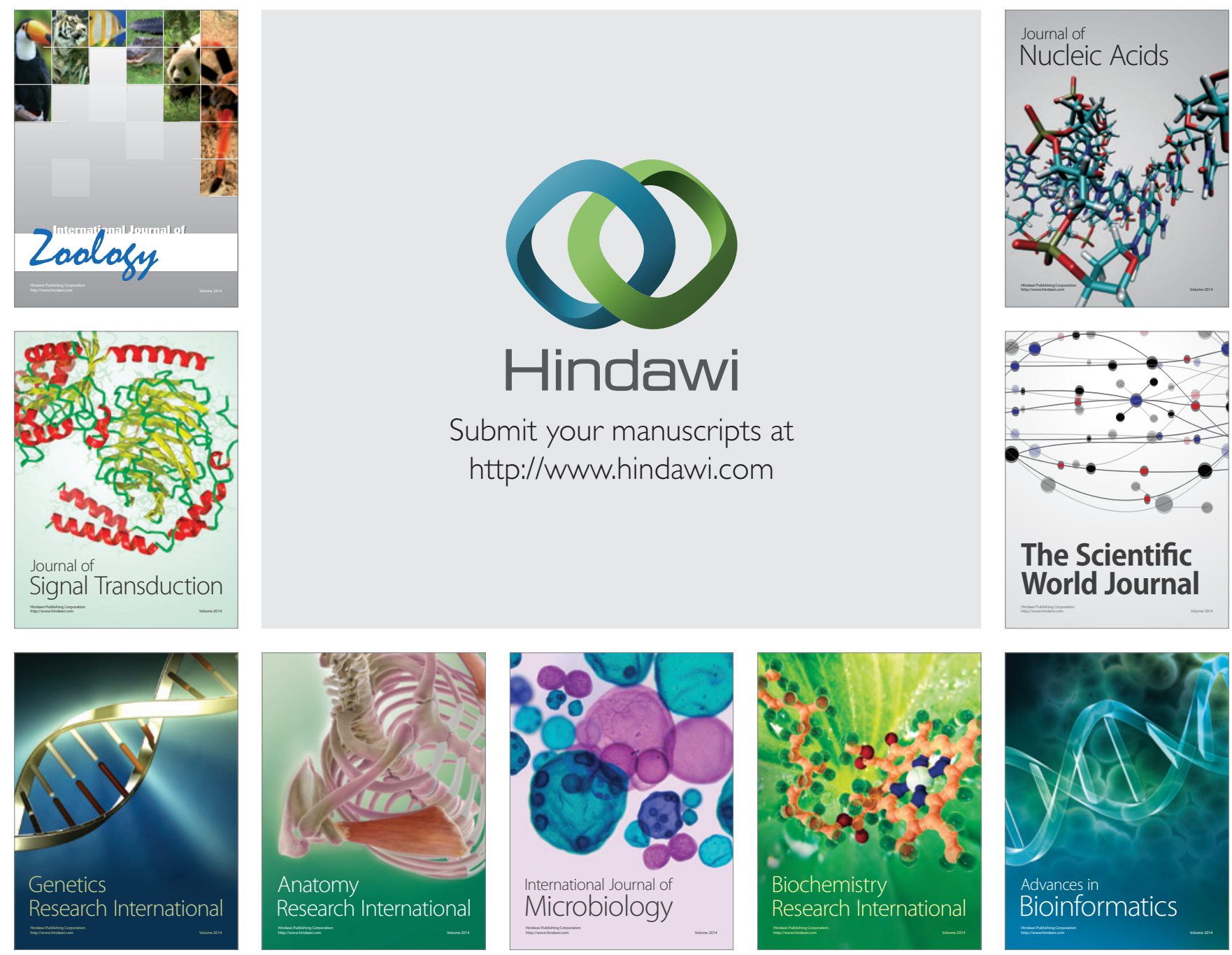

The Scientific World Journal
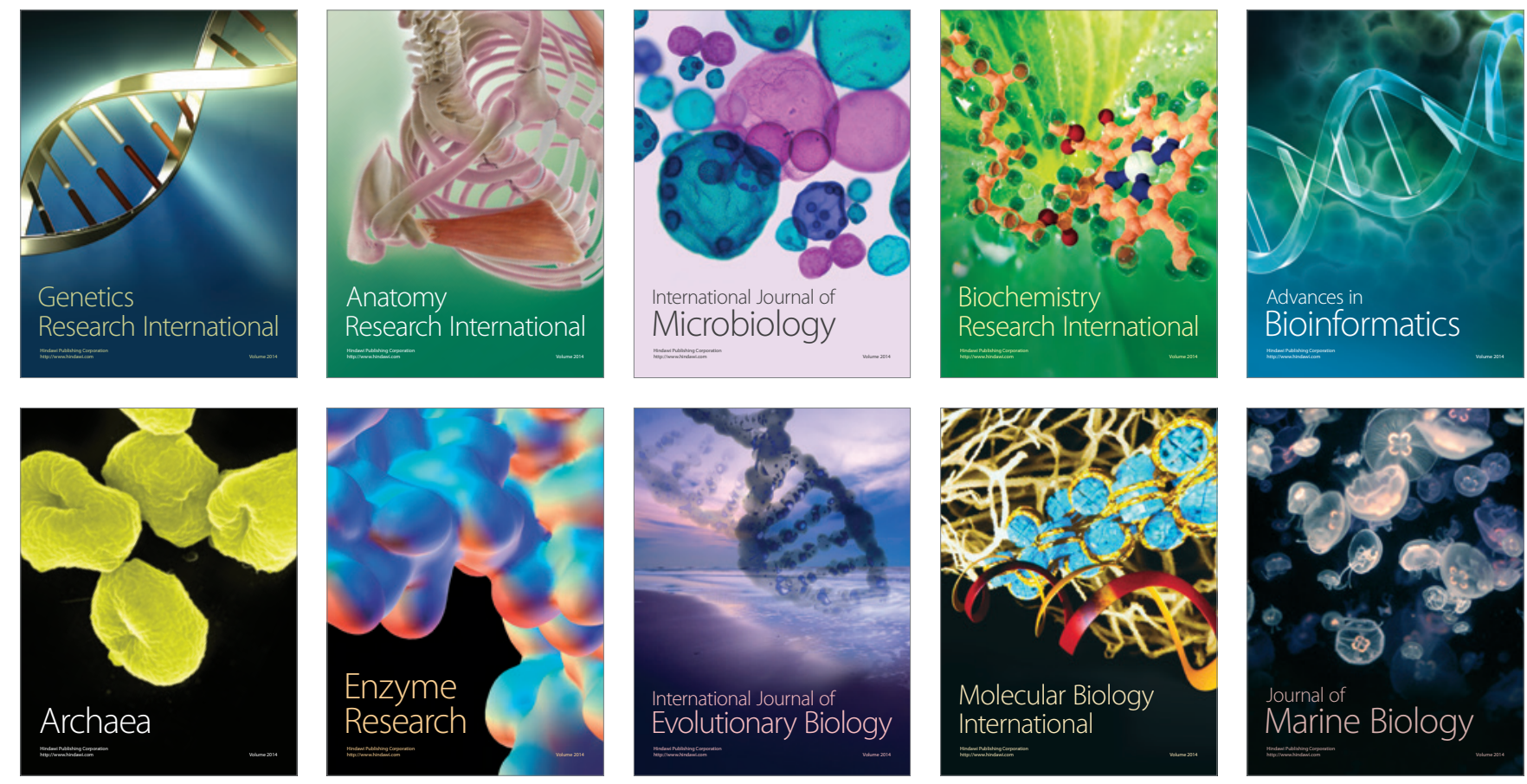